\title{
ALTERNATIVE VISIONS OF THE LEGAL PROFESSION IN SOCIETY: A PERSPECTIVE ON ONTARIO
}

\section{CAROLE CURTIS*}

The author presents a critical perspective of the legal profession and its governing body in Ontario. She relates her experience as a feminist bencher with the Law Society of Upper Canada, and describes feeling excluded from power. She questions the role of the Law Society in its current form, and concludes that it is outmoded.
L'auteure présente une perspective critique de la profession juridique et de son association professionnelle en Ontario. Elle fait part de son expérience en tant que membre féministe de la Law Society of Upper Canada, et dit s'être sentie exclue du pouvoir. Elle remet en question le rôle de la Law Society dans sa forme actuelle et la juge archaíque.

This is an effort to examine some of the assumptions which underlie our present notion of the legal profession. It is time to consider whether or not those assumptions continue to be valid, and whether there are changes coming that are deep enough and broad enough to warrant a wholesale reexamination of the present perception we have of the legal profession, including how we see ourselves as lawyers, how the public sees us, how our clients see us, and how government and other institutions we interact with see us. What are the consequences for lawyers of a wholesale reexamination of the present notion of the legal profession (an examination which is, I suggest, ongoing)? What is the impact on the right to self-regulation, on ethics, on our codes of conduct and on the way we deliver services? I am going to use some examples for you of things that have been happening in my province, Ontario, or Upper Canada, as it is sometimes called.

My analysis of the legal profession is influenced, of course, by my own perspective. I practice in a small firm (three lawyers). I am a feminist. I have a family law practice. I have a fair bit of legal aid in my practice. I have women as clients, but I do not act exclusively for women, since you can't make a living acting only for women. I act for children. I am left in politics and I am certainly left of the benchers. I am outside the mainstream and have rather an alternative kind of grass-roots practice. I have been an elected bencher in Ontario since 1991 (benchers are the governing body of Ontario's legal profession). I am, however, also a lawyer who has had a fair bit of access to power in the legal profession through executive positions in the governing bodies of the profession. I am also a woman who has had access to those positions, both in the Canadian Bar Association provincially and nationally, and at the law society where I have been a bencher for three years. However, I am a bencher who really feels excluded at the law society. I was elected, I suspect, by lawyers who feel excluded by the law society and who serve clients who feel excluded from power. In fact, in some ways, I feel that I was elected to be excluded.

I am also influenced in my perspective by the fact that, as a bencher, I discipline other lawyers, I am an adjudicator over their futures and I am an observer of lawyers in trouble. I also have the perspective of a lawyer who was disciplined (in 1993), who was accused and who was in trouble. 
How we see ourselves and how the public sees us is partly a function of the changing face of lawyers. It is too simple to consider that the changing face of lawyers means only the introduction of women, or lawyers from other cultures that are new to Canada, or native lawyers, or disabled lawyers, or gay and lesbian lawyers (all of which, together, form a group which the law society in Ontario calls "equity lawyers"). This is producing an interesting shift in perspective in the profession because we now have a lot of lawyers who are not white men. We have a lot of lawyers from groups that are powerless in our culture. The question we need to ask is whether they serve clients differently and whether they see the world differently, and if they do, whether this will redefine the profession and redefine codes of ethics. Well, of course it will change the profession. It has already changed the profession. But in what ways? What kind of impact will it have on self-regulation and on the whole question of professional responsibility?

Professional responsibility and codes of conduct are tied to specific norms of acceptable behaviour. How we use the rules of professional conduct and who we discipline reflects and delineates those ethics that we, as a profession, consider central. There have been several recent incidents in Ontario which paint a vivid and rather surprising picture of the status of the legal profession in Ontario. These incidents are the response of the profession in Ontario to two law society policy initiatives, a response which has been measured by written responses from the profession.

The law society in Ontario recently prepared a draft rule for the Code of Professional Conduct that deals with non-discrimination.' The rule is very basic; it says, in effect, "discrimination is professional misconduct." The rule lists the categories of discrimination that would qualify as professional misconduct and refers to professional employment. It refers to lawyers as employers, so that a lawyer could be found guilty of professional misconduct for behaviour as someone employing lawyers, staff and students, or as a lawyer dealing with the community, or as a lawyer dealing with other lawyers. The purpose of the rule was to educate and clarify the definition of discrimination, to incorporate a fairly simple gender analysis into the equation and into the definition, and to give lawyers some very specific and concrete examples of the sort of behaviour and policies which would constitute discrimination.

The rule really just sets out, in some detail, the current state of the law in Canada and Ontario regarding human rights legislation and human rights jurisprudence, including the Charter of Rights and Freedoms ${ }^{2}$ and its jurisprudence. The law society circulated the draft to the profession for comment before submitting it to convocation (the meeting of the benchers) for approval - a new tactic for the law society in Ontario, and a tactic which sounds suspiciously democratic. 
The written replies that were received were distributed to the benchers for consideration. The responses were truly astonishing! First of all, the written responses were very detailed and specific; they were quite angry; many of them were openly defiant. The saddest thing is that the responses showed a complete ignorance of the law. The profession told the law society in no uncertain terms that it had no business regulating lawyers as employers and that the way they ran their offices was not the law society's business - including the way they treated other lawyers and whom they hired as employees. The comments criticized the merits of the proposed rule. A significant number of solicitors seemingly do not know the laws which currently govern their own workplace and their obligations as employers. We have a legal profession in Ontario which apparently does not know the law and we have a surprising number of lawyers that have said openly and plainly (and I am quoting), "if you pass this rule, I will not obey it." It is interesting to consider what this means for the profession and for the law society.

The second initiative that received a lot of response was the proposed role statement of the law society. ${ }^{3}$ Some of the newer benchers have been encouraging a more corporate-like culture at the law society, including the development of a corporate vision, and there has been some pressure on the law society to respond to this view and make some changes. The law society in Ontario is a $\$ 35$ million a year operation with 380 employees. It was felt that it was difficult to determine what kinds of initiatives and programs would fit into the corporate vision, where no such vision is articulated.

The law society in Ontario drafted the kind of role statement you might expect. It refers to upholding the rule of law, the independence of the profession, honour and integrity, ensuring competence, and, most importantly, it talks about governing the profession in the public interest. In Ontario the law society has not, in recent tradition, seen itself as representing lawyers. It has seen itself as representing the public.

The committee instructed to draft the role statement was chaired by an inexperienced female bencher, a low-profile bencher, who may, in fact, have been "set up" in being assigned this task. Before the role statement was to be considered by convocation, it was circulated to the profession. Again, the law society got written replies from the profession, and again, took a fair bit of heat. Many members expressed dissatisfaction with the substance of the proposal. This includes the law society's own survey of members about the proposal. About half of the respondents to the survey rejected putting the public interest ahead of the profession's interest.

Other associations, such as the Canadian Bar Association in Ontario and several other lawyer's groups, also rejected that analysis. What they are demanding is that the law society in Ontario see as its proper role representing the interests of lawyers, and that the law society clearly articulate that role and include that role in any mission statement. What we now have is a profession which sees the law society's function in a completely different way than the law society itself sees it, and a profession which is demanding that the law society redefine its function. 
So what does this all mean for the profession at large? It means that we have differing views of the profession as between the governors and the governed. Harry Arthurs spoke to the benchers in Ontario at a strategic planning conference (September 1992), at which time he used a very insightful analysis about who the benchers are and who the benchers were. He noted that the benchers used to be elder statesmen and are now more like representatives of different constituencies. This is increasingly true in Ontario and it is having an impact on how the benchers govern. It will eventually have an impact, of course, on professional ethics and professional responsibility because there are differing world views, different life experiences, different professional experiences and different goals among the governors.

There is another recent incident that I want to present as an example of different world views. There was a discipline case regarding a lawyer in his fifties from a small town, who was accused of sexual harassment by a client in her fifties. She had been a client of his for ten years or so. He was doing a will for her and after he finished the will he told her that if she took off her blouse and showed him her breasts that he would do the will for free. She complained to the law society and he was disciplined. The way the benchers dealt with this incident and the way they responded to it was indicative of the disparity in world views among the benchers.

There was a real inability on the part of the benchers to look at the lawyer's behaviour from the perspective of the woman. There was, instead, a focus on that behaviour from the perspective of the perpetrator. This is Anita Hill's analysis, of course, of what is wrong with sexual harassment law and prosecutions in America; that is, the adjudicators identify with the perpetrator and view the behaviour from the perspective of the perpetrator rather than from the perspective of the victim. One bencher's explanation of this was that, after all, many benchers did not have women clients. While that may be true, I thought that a little odd, and wondered how many of them did not have mothers, or daughters or wives. Unfortunately, that bencher's analysis probably reflected the reaction of many of the benchers. The lawyer was found guilty of professional misconduct and was disciplined by a public reprimand in convocation.

The legal profession, historically, has performed an important social function as a protector of citizens' rights. The continued performance of this role really depends on our continued financial viability. There are some serious questions in Ontario about the continued viability of small firms and sole practitioners. There will be serious consequences for the public and for the profession itself, should it no longer be possible for sole practitioners or small firms to continue in the practice of law. The economic situation in Ontario is resulting in a restructuring of the profession's business format and of the education format. At the same time that the job market is declining severely, there is a large increase in the number of lawyers who are opening their own practices, though not all by choice.

Ontario has had for about two years a serious problem regarding articling positions; there is a severe shortage of them. Some students are articling for free as a result. A disproportionate number of the unemployed students are from the group that the 
benchers call equity lawyers. The law society has even taken the step of directly appealing to firms (e.g. "please hire"), but this has not fixed the problem. The benchers, however, are enormously reluctant to reexamine the entire education process. We require that students article before they can be called to the bar. The law society is still not willing to assume any responsibility for ensuring that there are enough jobs. So, finally, as a result of some pressure, the law society has struck a committee to examine this situation.

A similar issue is the cost of the bar admission course which, in Ontario, is enormously expensive. The gross cost is more than $\$ 5$ million. We just cannot afford to do this any more. Again, there is a real reluctance on the part of the law society to look at alternatives. The first committee that was struck to look at the problem started out by articulating as its mandate that "we all believe that the current structure of the Bar Admission Course is valuable and should be preserved."

The Ontario Legal Aid Plan has tremendous budget problems which resulted, in the fiscal year ending March 31,1994 , in the amount of $\$ 38$ million left owing to lawyers. Legal Aid funded its shortfall by borrowing $\$ 38$ million from the lawyers who do the work, essentially funding the plan on the overdrafts of the 6,000 lawyers in Ontario who work for clients on legal aid certificates. It is important to recognize that the majority of lawyers who do this work are in small firms or are sole practitioners. For example, as of June 9, 1994, Legal Aid owed my three-lawyer firm $\$ 94,000$. That situation is combined with the request of the law society to increase errors and omissions insurance premiums substantially. The result is that the premium will have quadrupled in the last three or four years in Ontario, and in 1994 it will be about $\$ 7,500$. Right now, one in six lawyers in Ontario has a claim against them. The rate of claims is 300 new claims a month. With a total bar of about 26,000 lawyers, soon nearly all of the practicing lawyers in the province would have claims against them, at this rate.

The result of these two problems is that the bar in Ontario is under financial pressure as never before. Many lawyers are in practices which are financially marginal, including mine. I say that unashamedly; I have worked very hard for sixteen years. This is not simply a situation of financial circumstances being difficult for many lawyers. This is, in fact, so serious that many lawyers will close their practice as a result. One senior bencher even estimated that as many as 20 to 25 percent of the bar could be leaving the profession.

While it is interesting to see how the law society will respond to this dilemma, it has not gone unnoticed by the law society that such large numbers of resignations would seriously erode its revenue base. The financial problems are also producing discipline problems. The immediate response of that analysis would be to imagine an increase in the theft of trust funds. Instead, what we have are lawyers whose financial problems are so serious that one of the first things to suffer is bookkeeping and accounting, because the lawyer cannot afford those services. Such lawyers do not make their annual filings, they get suspended and then they get disciplined, so that they have a combination of an administrative suspension and a discipline problem. In May 1994, 
I heard two days of discipline hearings and at least a third of the cases were this kind of situation. It was terribly sad. Law societies need to find another way to deal with these problems.

It is worth examining who the governors of the profession are and why this is important. The benchers used to be - and perhaps still largely are - a group of lawyers that were all rather alike. In Ontario we have forty elected benchers, four community representatives appointed by the Attorney General and an additional twentyfour benchers who have ex-officio status. Approximately seven of the ex-officio benchers have the right to vote - all former treasurers (the senior position) have that right. Currently, only 25 percent of the elected benchers are women. The issue of who has a vote is a serious one; there are currently three former treasurers, who served in the 1960 s, that have the right to vote. All of them are over eighty years old; one might ask: "what is their constituency?"

There are very real conflicts in the law society in Ontario that contribute to the difficulty the law society faces in conducting business. There are conflicts based on gender lines, based on political lines and based on generational lines. The law society in Ontario is a place that is openly hostile to women. It has long had a reputation as a "boy's club." Many benchers openly and unashamedly admit this, wistfully remembering the old days and lamenting the changes that have taken place. What does that mean? It means that if women, who are not a minority group, are excluded, this is a serious message for other traditionally excluded groups. It is facile to use the word "minority" to describe these groups, but it is terribly marginalizing to identifiable groups which are already marginalized in our culture. The rooms where the benchers meet and socialize and decide discipline matters at the law society in Ontario are covered with portraits of dead white men. Our law society is not a place that is open to change or to new directions.

The time commitment required to run the profession in Ontario is inappropriately high. I spend an average of forty hours a month on law society business - time that I donate free. To translate that into numbers that are meaningful to lawyers, the same expenditure of time, paid even at the legal aid rate in Ontario ( $\$ 79.56$ per hour) would produce over $\$ 38,000$ in billings. The combination of the joint crisis in errors and omissions insurance and legal aid resulted in bencher time for me of sixty-two hours in May 1994 and seventy-eight hours in June 1994. This is financially crippling. It makes it impossible for small firms to be part of the governing structure.

It is also worthwhile to consider the way the profession sees the law society and the impact that has on the law society's ability to govern the profession. I still think of the law society as "they"; I do not think of it as "we." It does not feel like "we." Before we as a profession are able to change, we need to change who governs the profession.

In closing, I am including the entire text of a letter from Jane E. Hegney that was published in the May 1994 issue of the Law Times (a legal trade paper). It is a letter from a woman practicing in London, Ontario, who is commenting on a earlier article in the Law Times on gender politics at the law society: 
I am afraid I must disagree with bencher Mary Weaver's assertion that "Convocation is keeping up in reflecting society." The problem is that it is not.

I feel I have no common ground with most of the benchers, given that I am a young woman with a family, practising law outside of Toronto in a small firm, trying to survive predominantly on legal aid. How many benchers lost sleep wondering how they were going to pay the first half of the fees and errors and omissions premium two weeks ago? How many benchers feel that another increase in levies will force them out of practice?

This is why I view the Law Society of Upper Canada as having no relevance in my life except as a policing body and as a levier of exorbitant fees. The less I am involved with the law society, the happier I am. I suspect others share this attitude, which may explain why the bencher election has such low voter participation.

The article indicates that Convocation is far from a welcoming place for women, even those who have succeeded on male terms, whom I expect to be credible to and respected by their male colleagues. Apparently they are not. When I read of the struggle these women have, what confidence can I have that issues important to me will be considered or even raised in Convocation.

At the next bencher election, I will be looking for candidates that are more "reflective of society." Will there be any? 


\section{APPENDIX I \\ RESEARCH AND PLANNING COMMITTEE \\ SUBCOMMITTEE ON THE ROLE OF THE LAW SOCIETY \\ June 24, 1994}

\section{ROLE STATEMENT}

The Law Society of Upper Canada exists to govern the legal profession in the public interest by:

- ensuring that the people of Ontario are served by lawyers who meet high standards of learning, competence and professional conduct; and

- upholding the independence, integrity and honour of the legal profession;

for the purpose of advancing the cause of justice and the rule of law. 


\section{APPENDIX II}

\section{THE LAW SOCIETY OF UPPER CANADA PROPOSED RULE ON NON-DISCRIMINATION}

Draft of June 25, 1993

The following proposed Rule of Professional Conduct is being circulated to members of the profession for their comments and suggestions.

\section{RULE 28}

Discrimination by the lawyer on the grounds of race, ancestry, place of origin, colour, ethnic origin, citizenship, creed, sex, sexual orientation, age, record of offences,' marital status, family status, or disability with respect to professional employment of other lawyers, articled students or any other person, or in professional dealings with other members of the profession or any other person is professional misconduct. ${ }^{2}$

\section{COMMENTARY}

1. The Law Society of Upper Canada acknowledges the diversity of the community of Ontario, in which its members serve, and expects members to respect the dignity and worth of all persons and to treat all persons equally, without discrimination. Members must ensure that no one is denied services, or receives inferior service, on the basis of any of the grounds noted in the Rule. Members must ensure that their employment practices do not offend the Rule. Discrimination in employment or in the provision of services not only constitutes professional misconduct, it violates the Ontario Human Rights Code.

2. For the purposes of this Rule, discrimination includes the following:

a) Any action or omission which effectively denies to an individual or group benefits or opportunities available to others, on the basis of any of the grounds noted in the Rule.

b) Maintenance of requirements, rules, qualifications or considerations which, while they may appear to be neutral, and may be applied uniformly, have an adverse effect on an individual or group on the basis of any of the grounds noted in the Rule. Such requirements, rules, qualifications or considerations will be acceptable only if they are reasonable and bona fide, and accommodation of the affected individual or group is not possible without undue hardship to the member.

c) Sexual harassment as defined in Rule 27.

d) Harassment, that is, engaging in vexatious [sic] comment or conduct that is known or ought reasonably to be known to be unwelcome and that affects an individual or group on the basis of any of the grounds other than sex noted in the Rule. 
e) Failure by the member to take reasonable steps to prevent or stop discrimination by the member's partner or by any employee or agent who is subject to the member's direction or control. ${ }^{3}$

3. Discrimination can be constituted by the effect of action or omission. Intent to discriminate is not a prerequisite to a finding of discrimination.

4. Discrimination does not include special programs designed to relieve disadvantage for individuals or groups identified on the basis of the grounds noted in this Rule.

5. The Rule applies to the conduct of any member in any aspect of the provision of professional service, whether the action or omission at issue is that of the member, the member's partner or any employee or agent subject to the member's direction or control.

6. The Rule applies to discrimination by the member in any aspect of the provision of employment, including recruitment, promotion, training, transfer, receipt of benefits, dismissal, lay-off, discipline, performance appraisal and working conditions such as overtime, hours of work and shift work. It applies to all discrimination with workplace repercussions, regardless of where it occurs, for example physical work sites, cafeterias, washrooms, elevators, conferences, business travel, on the telephone and office parties.

7. Discriminatory attitudes on the part of partners, employees, ${ }^{4}$ agents or clients ${ }^{5}$ do not diminish the responsibility of the member to refrain from discrimination in the provision of service or employment.

8. Discrimination may be inadvertent and unintended. The following are examples of practices that may be discriminatory in effect unless it can be demonstrated that they are reasonable and bona fide and that those affected cannot be accommodated without undue hardship to the member:

a) Setting unnecessary hiring criteria that have the effect of excluding job applicants on prohibited grounds e.g. while it may be reasonable (depending on the size of the firm and the number of students) to require that all articling students be able to go wherever the job requires, a requirement that the student have a driver's licence or a car effectively excludes persons with disabilities that prevent them from obtainig a driver's licence. ${ }^{6}$

b) Asking questions during an employment or promotion interview that are not logically related to the essential requirements of the job, ${ }^{7}$ e.g. asking the candidate whether he or she is married or intends to have children, thereby discriminationg on the basis of family status or sex, or asking the candidate whether he[sic] or she can "handle" racial harassment, thereby discriminating on the basis of race. ${ }^{8}$

c) Failing to provide appropriate parental leave, thereby discriminating on the basis of family status or sex. ${ }^{9}$ 
d) Failing to accommodate religious holiday ${ }^{10}$ or religious practices such as wearing turbans. ${ }^{11}$

e) Denying an applicant a job because of the applicant's accent, where the applicant's English-language skills are adequate, thereby discriminating on the basis of ancestry or place of origin. ${ }^{12}$

f) Maintaining an insurance policy that denies pregnancy or non-pregnancyrelated benefits to employees during pregnancy or maternity leave, thereby discriminating on the basis of sex. ${ }^{13}$

g) Maintaining practices based on untested assumptions rather than individual ability, such as steering women, students with a disability or associates away from litigation, thereby discriminating on the basis of $\operatorname{sex}^{14}$ or disability ${ }^{15}$ respectively.

h) Requiring billable hours or workload expectations which effectively exclude those who have childcare responsibilities and adversely impacting such persons on the basis of family status or sex.

9. The elimination or avoidance of discrimination requires the accommodation of diversity. Such accommodation is expected unless it would cause undue hardship to the member. The following are examples of the kind of accommodation that may be required:

a) The provision of flexible work hours to accommodate family responsibilities, or to accommodate transportation difficulties for persons with disability.

b) The modification of the physical workplace to include wheelchair access, modified furniture and assistive devices.

c) An appropriate policy for health-related absences from employment. ${ }^{16}$

d) A benefits policy that encompasses same-sex couples. ${ }^{17}$

e) Accommodation of religious holidays or religious practices such as the wearing of a turban. ${ }^{18}$

f) Extending equal courtesy to all persons without regard to accent or other characteristics related to any of the grounds of the Rule.

10. Various factors will be considered in assessing the seriousness of violations of this Rule, such as,

- the severity of the consequences to the person who has been discriminated against;

- whether the member has previously been found to have violated this Rule, Rule 27 or the Human Rights Code;

- whether the person who has been discriminated against was subjected to coercion, assault, threats or reprisals;

- whether the conduct behind the breach of this Rule was premeditated or repetitive;

- whether there was wilful or reckless damage to the self-esteem, emotional health, physical health or ability to function effectively of the person who has been discriminated against.

11. "Record of offences" means a conviction for, 
a) an offence in respect of which a pardon has been granted under the Criminal Records Act (Canada) and has not been revoked, or

b) an offence in respect of any provincial enactment.

Record of offences is a prohibited ground only in relation to the provision of employment. Discrimination in employment on the basis of record of offences does not infringe on this Rule if the requirement regarding record of offences is a reasonable and bona fide occupational qualification because of the nature of the employment. ${ }^{19}$

12. Discrimination in employment on the basis of disability is not a violation of this Rule if the person who is discriminated against is incapable of performing or fulfilling the essential duties or requirements of the job, and accommodation is not possible without undue hardship to the member.

\section{NOTES}

1. In respect of employment decisions, see Commentary 11 for the definition of record of offences and a discussion of reasonable and bona fide exceptions.

2. See the Human Rights Code, R.S.O. 1990, c. H. 19, part I and s. 10.

3. Robichaud v. Canada (Treasury Board) (1987), 8 C.H.R.R. D/4326 (S.C.C.); Persaud v. Consumers Distributing (1990), 14 C.H.R.R. D/23 (Ont. Human Rights Comm. Bd. of Inquiry); Lee v. T.F. Applebee's Food Conglomeration, 9 C.H.R.R. D/4781 (Ont. Human Rights Comm. Bd. of Inquiry).

4. Renaud v. Board of Education of Central Okanagan No. 23 and C.U.P.E., Local 523 (1992) 141 N.R. 185 (S.C.C.); Imberto v. Vic and Tony Coiffure (1981), 9 C.H.R.R. D/392 (Ont. Human Rights Comm. Bd. of Inquiry).

5. Loland v. Forbirich Enterprises Lid. (1991), 13 C.H.R.R. D/87 (B.C. Human Rights Council); Bouchard v. Canada (Canadian Armed Forces) (1990), 13 C.H.R.R. D/111 (Cdn. Human Rights Trib.); De Jong v. Horlacher Holdings Ltd. (1989), 10 C.H.R.R. D/6283 (B.C. Human Rights Council); Stefanyshyn v. 4 Season Management Lid. (4 Seasons Racquet Club) (1986), 8 C.H.R.R. D/3934 (B.C. Human Rights Council).

6. Onischak v. British Columbia (1990), 13 C.H.R.R. D/87 (B.C. Human Rights Council); Canada (Attorney General) v. Rosin [1991], I F.C. 391 (C.A.); Phalen v. Solicitor General of Canada (1980), 2 C.H.R.R. D/433 (Canadian Human Rights Tribunal); Foreman v. VIA Rail Canada Inc. (1980), 1 C.H.R.R. D/III (Canadian Human Rights Tribunal).

7. S. 23 of the Human Rights Code. See also Taylor v. Via Security Systems Inc. (1987), 8 C.H.R.R. D/3925 (Ont. Human Rights Comm. Bd. of Inquiry); Lindahl v. Auld Philips Lid. 1986), 7 C.H.R.R. D/3396 (B.C. Council of Human Rights) (complainant with cleft palate tumed down for job as retail sales manager).

8. Suchit v. Sisters of St. Joseph's for the Diocese of Toronto (1983), 4 C.H.R.R. D/1329 (Ont. Human Rights Comm. Bd of Inquiry); Downey v. Metropolitan Transit Commission (1991), 14 C.H.R.R. D/487 (Nova Scotia Bd. of Inquiry). 
9. Canada (Minister of National Defence) v. Mangrain (1992), 1 F.C. 472 (C.A.); Wormsbecker v. Super Valu and Westfair Foods Ltd. (1980), 2 C.H.R.R. D/348 (Sask. Bd. of Inquiry); Century Oils (Canada) Inc. v. Davies (1988), 9 C.H.R.R. D/4659 (B.C.S.C.) aff'g (1986), 8 C.H.R.R. D/3770 (sub nom. Davies v. Century Oils (Canada) Inc. (B.C. Human Rights Council); Paton v. Brouwer and Co. (1984), 5 C.H.R.R. D/1946 (B.C. Council of Human Rights).

10. Re Ontario Human Rights Commission and Simpsons-Sears Lid. (1985), 23 D.L.R. (4th) 321 (S.C.C.); see also Central Alberta Dairy Pool v. Alberta (Human Rights Commission) (1990), 72 D.L.R. (4th) (S.C.C.); Board of Education of Central Okanogan and Professional Employees International Union, Local 267 v. Domtar Inc. (1992), 8 O.R. (3d) 65 (Gen. Div.); Re Chrysler Canada Ltd. and United Automobile Workers, Local 444 (1986), 23 L.A.C. (3d) 366 (Arbitrator), and van Gaalen v. Fabricland Distributors Lid. (1988), 10 C.H.R.R. D/5666 (B.C. Human Rights Council).

11. Singh v. Security and Investigation Services Ltd. unreported, (Ont. Human Rights Comm. Bd. of Inquiry May 31, 1977); see also Khalsa v. Co-op Cabs (1980), 1 C.H.R.R. (Ont. Human Rights Comm. Bd. of Inquiry) and Pannu v. Prestige Cab Ltd. (1986), 8 C.H.R.R. D/3709 (Alta. Bd. of Inquiry); Sehdev v. Bayview Glen Junior Schools Lid. (1985), 9 C.H.R.R. D/4881 (Ont. Human Rights Comm. Bd. of Inquiry); Pandori v. Peel Bd. of Education (1990), 12 C.H.R.R. D/364 (Ont. Human Rights Comm. Bd. of Inquiry).

12. Gajecki v. Surrey School District No. 36 (1990), 11 C.H.R.R. D/326 (B.C. Council of Human Rights).

13. Brooks v. Canada Safeway Ltd. (1989), 59 D.L.R. (4th) 321 (S.C.C.).

14. Corrigan v. Pacific Western Airlines Lid. (1988), 9 C.H.R.R. D/4993 (Canadian Human Rights Tribunal); Re Knit-Rite Mills Ltd. and MacDonald (1985), 34 Man. R. (2d) 77 (Q.B.) affg (1983), 5 C.H.R.R. D/1949 (Bd. of Adjudication).

15. Shaw v. Levac Supply Ltd. (1990), 14 C.H.R.R. D/36 (Ont. Human rights Commission Bd. of Inquiry); B.C. Timber Lid. (Skeena Pulp Division) v. Pulp, Paper and Woodworkers of Canada, Local No. 4 (1983), 4 C.H.R.R. D/1557 (B.C. Labour Arbitration Board); La Commission des droits de la Personne du Quebec c. Les Boutiques du Tricot (1983), 5 C.H.R.R. D/2003 (Que. Prov. Ct.); Swanson v. Steveshirl Restaurant (1985), 6 C.H.R.R. D/2662 (B.C. Human Rights Council); Barton v. New Brunswick Electric Power Commission (1981), 2 C.H.R.R. D/54I (N.B. Bd. of Inquiry); Lindahl v. Auld Philips Lid. supra note 6 (1986), 7 C.H.R.R. D/3396 (B.C. Council of Human Rights); Cameron v. Nel-Gor Castle Nursing Home (1984), 5 C.H.R.R. D/2170 (Ont. Human Rights Bd. of Inquiry); Re Wentworth County Board of Education and canadian Union of Public Employees, Local 1572 (1984), 14 L.A.C. (3d) 310 (Arbitration Board); Roy v. British Columbia Rail Ltd. (1986), 8 C.H.R.R. D/3646 (B.C. council of Human Rights), add'l reasons at (1987), 8 C.H.R.R. D/4193 (B.C. council of Human Rights); Bouchard v. Canada (Canadian Armed Forces) (1990), 13 C.H.R.R. D/111 (Cdn. Human Rights Trib.); Belliveau v. Steel Co. of Canada (1988), 9 C.H.R.R. D/5250 (Ont. Human Rights Comm. Bd. of Inquiry); Hamlyn v. Cominco (1990), 11 C.H.R.R. D/333 (B.C. Council of Human Rights); Funk v. Siowe-Woodward Inc. (1987), 8 C.H.R.R. D/4024 (B.C. Human Rights Council) add'I reasons at (1987), 8 C.H.R.R. D/4337 (B.C. Council of Human Rights).

16. Bielecky v. Young, Macnamara, unreported (December 15, 1992 Ont. Human Rights Comm. Bd. of Inquiry) digested in the Lawyers Weekly v. 12 n. 37 p. 14; Allum v. Hollyburn Properties Management Inc. (1991), 15 C.H.R.R. D/171 (B.C. Council of Human Rights).

17. Leshner v. Ontario (No.2) (1992), 16 C.H.R.R. D/184 (Ont. Human Rights Comm. Bd. of Inquiry).

18. Supra notes 10-11.

19. Woodward Store Ltd. v. McCartney (1983), 4 C.H.R.R. D/1325 (B.C.S.C.) at D/1327. 